\title{
Antiproliferative and apoptotic effects of proteins from black seeds (Nigella sativa) on human breast MCF-7 cancer cell line
}

\author{
Yamna Khurshid ${ }^{1,2}$, Basir Syed', Shabana U. Simjee ${ }^{2}$, Obaid Beg ${ }^{2}$ and Aftab Ahmed ${ }^{1 *}$
}

\begin{abstract}
Background: Nigella sativa (NS), a member of family Ranunculaceae is commonly known as black seed or kalonji. It has been well studied for its therapeutic role in various diseases, particularly cancer. Literature is full of bioactive compounds from NS seed. However, fewer studies have been reported on the pharmacological activity of proteins. The current study was designed to evaluate the anticancer property of NS seed proteins on the MCF-7 cell line.

Methods: NS seed extract was prepared in phosphate-buffered saline (PBS), and proteins were precipitated using $80 \%$ ammonium sulfate. The crude seed proteins were partially purified using gel filtration chromatography, and peaks were resolved by SDS-PAGE. MTT assay was used to screen the crude proteins and peaks for their cytotoxic effects on MCF-7 cell line. Active Peaks (P1 and P4) were further studied for their role in modulating the expression of genes associated with apoptosis by real-time reverse transcription PCR. For protein identification, proteins were digested, separated, and analyzed with LC-MS/MS. Data analysis was performed using online Mascot, ExPASy ProtParam, and UniProt Knowledgebase (UniProtKB) gene ontology (GO) bioinformatics tools.
\end{abstract}

Results: Gel filtration chromatography separated seed proteins into seven peaks, and SDS-PAGE profile revealed the presence of multiple protein bands. Among all test samples, P1 and P4 depicted potent dose-dependent inhibitory effect on MCF-7 cells exhibiting IC 50 values of $14.25 \pm 0.84$ and $8.05 \pm 0.22 \mu \mathrm{g} / \mathrm{ml}$, respectively. Gene expression analysis demonstrated apoptosis as a possible cell killing mechanism. A total of 11 and 24 proteins were identified in P1 and P4, respectively. The majority of the proteins identified are located in the cytosol, associate with biological metabolic processes, and their molecular functions are binding and catalysis. Hydropathicity values were mostly in the hydrophilic range.

Conclusion: Our findings suggest NS seed proteins as a potential therapeutic agent for cancer. To our knowledge, it is the first study to report the anticancer property of NS seed proteins.

Keywords: Nigella sativa seed, Protein purification, Anticancer activity, Apoptosis, LC-MS/MS

\section{Background}

Breast cancer is the leading cause of cancer-related death in women accounting for 2.1 million new cases and 627,000 deaths globally in 2018 according to the last release of GLOBOCAN data [1]. Considering the fact of increasing burden and downside of current therapies available for breast cancer, search for new effective drugs is important. One most prominent hallmark in all

\footnotetext{
* Correspondence: aahmed@chapman.edu

${ }^{1}$ Biomedical and Pharmaceutical Sciences, Chapman University School of

Pharmacy, 9401 Jeronimo Road, Irvine, CA 92618, USA

Full list of author information is available at the end of the article
}

malignant cells is evasion from apoptosis and is triggered either by the intrinsic mitochondrial pathway or extrinsic death receptor-mediated pathway [2]. Irrespective of the pathway involved in apoptosis, the execution is mediated by a cascade of cysteine-aspartic proteases named as caspases that are further categorized into initiator caspases (caspase 2, 8, 9 and 10) and executioner caspases (caspase 3, 6 and 7). Therefore, inducing apoptosis is a pivotal approach in fighting against tumor [3].

Historically, compounds derived from medicinal plants serve as a promising source of pharmaceuticals for numerous ailments. According to the World Health 
Organization (WHO), more than $80 \%$ of the population around the globe depend entirely on medicinal plants and herbal remedies for their treatment [4]. Plantderived compounds account for more than $60 \%$ of the approved anticancer drugs [5, 6], including taxol, vincristine, vinblastine, and camptothecin derivatives [7]. Despite years of research and many treatment options available toxicity, off-targets, drug resistance, and limited bioavailability remain a challenge on the way to complete cure. With the advancement in proteomics, protein-based drugs emerged out as a potential anticancer agent [8]. These drugs offer many advantages over small molecules as they are highly potent and selective therefore, less toxic [9]. Medicinal plants are a rich source of biologically active proteins and peptides particularly those belonging to Solanaceae, Ranunculaceae, Brassicaceae, Asteraceae, Fabaceae, and Cucurbitaceae families [10]. Evaluation of protein and peptides from these families for their anticancer potential could provide a piece of preliminary information for the selection of plants with potent antitumor activity for future studies.

Nigella sativa (NS), a medicinal herb frequently known as black seed or Kalonji, is a member of a Ranunculaceae family, well known for its pharmacological action against various human diseases [11]. Its cultivation is native to Southwest Asia, Southern Europe, and North Africa [12]. The seeds of NS reported to contain fats $(28.5 \%)$, proteins $(26.7 \%)$, carbohydrates $(24.9 \%)$, crude fibers $(8.4 \%)$ and ash content $(4.8 \%)[13,14]$. To date, more than 100 bioactive compounds, including thymoquinone, alkaloids (nigellidine, nigellicine), phenol (carvacol), and saponin (alpha-hederin) have been reported from NS [15]. These compounds have been shown to possess a wide range of activities, including anticancer, antimicrobial, anti-diabetic, analgesic, immunomodulatory, diuretic, antihypertensive, hepatoprotective, spasmolytic, gastroprotective, renal protective, a bronchodilator, and antioxidant properties [16]. However, limited literature is available on the pharmacological activity of NS seed proteins. Recently, two novel thionins named NsW1 and NsW2 reported potent against Staphylococcus aureus, Bacillus subtilus and Candida albicans [17]. Previously, isolated defensin peptides, Ns-D1, and Ns-D2 have also shown a strong inhibitory response against various strains of phytopathogenic fungi [18]. To the best of our knowledge, proteins from NS seeds have not been studied for their anticancer potential yet. Hence, the present study was designed to demonstrate the effect of NS seed protein extract and partially purified proteins on human MCF7 breast cancer cell line. Their effect on the expression of pro- and anti-apoptotic genes is also investigated to determine tumor cell killing mechanisms. Furthermore, active proteins were identified using high- resolution mass spectrometer and classified based on their cellular compartment, biological process, and molecular functions.

\section{Method \\ Plant material}

NS seeds were bought from the local grocery store of Karachi, Pakistan. It was, authenticated based on morphology by Dr. Muneeba Khan, Taxonomist at Center for Plant Conservation, University of Karachi Herbarium, and Botanical Garden. Voucher specimen has been deposited, but no deposition number available. As per institutional policy, seeds are not accepted as a voucher specimen for submission; therefore, deposition number is issued for whole plants only. Debris and other particles were removed by handpicking, and seeds were grounded into a fine powder using a food processor.

\section{Protein extraction}

The proteins were extracted using a previously described method with minor modification [19]. In brief, $200 \mathrm{~g}$ of seed powder was dissolved in phosphate-buffered saline (PBS) $1 \mathrm{X},(1: 10 \mathrm{w} / \mathrm{v}) \mathrm{pH} 7.2$, for overnight at $4{ }^{\circ} \mathrm{C}$ with continuous stirring. Following this, seed extract was centrifuged for $30 \mathrm{~min}$ at $4{ }^{\circ} \mathrm{C}$ and $10,000 \mathrm{rpm}$, the supernatant was separated, and $80 \%$ ammonium sulfate was added to the supernatant at $4{ }^{\circ} \mathrm{C}$. The next day, the protein precipitates were obtained by centrifugation at similar conditions. The pellet was dissolved in PBS, dialyzed in deionized water, and lyophilized.

\section{Gel filtration chromatography}

The crude seed protein extract was fractionated on ÄKTA start (GE Healthcare) fast protein liquid chromatography (FPLC) system equipped with a $280 \mathrm{~nm}$ detector and automated fraction collector. A $300 \mathrm{mg}$ of crude seed protein sample was loaded onto Hiload ${ }^{\text {tw }} 16 /$ 60 Superdex $^{\text {Tw }} 200 \mathrm{pg}$ gel filtration column (GE Healthcare) pre-equilibrated with PBS. All fractions were collected at a flow rate of $1 \mathrm{ml} / \mathrm{min}$ ( $5 \mathrm{ml}$ in each tube), and absorbance was recorded at $280 \mathrm{~nm}$.

\section{Protein estimation by Bradford assay}

The crude seed proteins and gel filtration peaks were quantified using commercially available Coomassie Bradford assay kit (Thermo Fisher Scientific, USA) following the provided protocol. Briefly, $5 \mu \mathrm{l}$ of standard bovine serum albumin and protein sample were added to 96-well plate, and $250 \mu \mathrm{l}$ of Bradford reagent was added and mixed gently. All the samples were analyzed in triplicates. After 10 min of incubation, absorbance was measured at $595 \mathrm{~nm}$ wavelength using a microplate photometer. 


\section{Sodium dodecyl sulfate-polyacrylamide gel electrophoresis (SDS-PAGE)}

The crude proteins of NS seed and gel filtration chromatography peaks were resolved on 4-20\% Tris/glycine precast Mini- PROTEAN TGX gels (Bio-Rad) using Mini-PROTEAN Tetra Cell assembly (Bio-Rad). A $15 \mu \mathrm{l}$ of 2X Laemmli sample buffer (Bio-Rad) containing 2mercaptoethanol was mixed with $15 \mu \mathrm{l}(20 \mu \mathrm{g})$ of sample, heated at $95^{\circ} \mathrm{C}$, and run at a constant volt of $200 \mathrm{~V}$ for $45 \mathrm{~min}$. To visualize protein bands, the gels were stained with Coomassie Blue R-250 [20].

\section{Cell culture}

The human breast cancer cell line MCF-7 (ATCC HTB$\left.22^{\mathrm{m}}\right)$ used in this study was obtained from Dr. Panjwani Center for Molecular Medicine and Drug Research (PCMD) Biobank. Cells were maintained in DMEM medium supplemented with fetal bovine serum (FBS) $10 \%(\mathrm{v} / \mathrm{v})$ and penicillin-streptomycin $1 \%(\mathrm{v} / \mathrm{v})$ in a humidified incubator at $37^{\circ} \mathrm{C}$ containing $5 \% \mathrm{CO}_{2}$.

\section{MTT assay for cell viability}

MTT [3-(4, 5-dimethylthiazol-2-yl)-2, 5-diphenyl tetrazolium bromide] assay was utilized to measure the antiproliferative potential of NS seed proteins [21]. Briefly, $3 \times 10^{4}$ cells $/ \mathrm{ml}$ were cultured in 96 - wells plates in $200 \mu \mathrm{l}$ of volume and incubated at $37^{\circ} \mathrm{C}$ in $5 \% \mathrm{CO}_{2}$ for $24 \mathrm{~h}$. The next day, the medium was removed, and for screening, cells were treated with different concentrations $(25,50,100,200$, and $400 \mu \mathrm{g} / \mathrm{ml})$ of NS seed crude protein and gel filtration chromatography peaks for $48 \mathrm{~h}$. As only peak 1 (P1) and peak 4 (P4) exhibited cytotoxic response against MCF-7 therefore, they are further selected for finding $\mathrm{IC}_{50}$ and treated at a dose of $(10,20$, 40 , and $60 \mu \mathrm{g} / \mathrm{ml})$ for $\mathrm{P} 1$ and $(5,10,20$, and $40 \mu \mathrm{g} / \mathrm{ml})$ for P4.In control cells, only medium was added, and doxorubicin was used as a standard drug. After $48 \mathrm{~h}$, MTT dye $(0.5 \mathrm{mg} / \mathrm{ml})$ prepared in $200 \mu \mathrm{l}$ medium was added to the individual well and incubated at $37^{\circ} \mathrm{C}$ in $5 \% \mathrm{CO}_{2}$ for $4 \mathrm{H}$. medium containing dye was removed after incubation, and purple formazan crystals were solubilized in $100 \mu \mathrm{l}$ of DMSO. Absorbance was recorded at $550 \mathrm{~nm}$ wavelength using a Multiskan FC Microplate Photometer (Thermo Fisher Scientific, USA). The percentage of cell inhibition was calculated using the formula:

$$
\text { Percent Inhibition }=\frac{(\text { O.D.of untreated cells-O.D.of treated cells }) \times 100}{\text { O.D.of untreated cells. }}
$$

RNA isolation and cDNA synthesis

MCF-7 $1 \times 10^{6}$ cells/well were seeded in a 6-well plate and placed in $37^{\circ} \mathrm{C}$ incubator having $5 \% \mathrm{CO}_{2}$. After 24 h, MCF-7 cells were treated with P1 (10 and $14 \mu \mathrm{g} / \mathrm{ml})$ and P4 $(5$ and $8 \mu \mathrm{g} / \mathrm{ml})$. The total RNA was isolated by using TRIzol reagent (Invitrogen) following the manufacturer's instruction. The isolated RNA was run on $1.2 \%$ agarose gel electrophoresis for $45 \mathrm{~min}$ at $80 \mathrm{~V}$ to determine the integrity and quantified using NanoDrop 2000 Thermo Scientific spectrophotometer. Samples with high yield, good integrity, and purity ratio 260/280 of $\sim 2$ were selected for cDNA synthesis. cDNA was synthesized using the RevertAid First Strand cDNA synthesis kit (Thermo Scientific, USA) in Eppendorf Mastercycler ${ }^{\circ}$ Pro thermal cycler (USA) according to manufacturer's instructions.

\section{Real time PCR for gene expression analysis}

qPCR was performed in Stratagene Mx3000P (Agilent Technologies, USA) instrument by using Maxima SYBR Green/ROX qPCR master mix kit (cat\# K0221; Thermo Scientific) as per manufacturer's protocol. After amplification, melting curve analysis was performed by following the method; $95^{\circ} \mathrm{C}$ for $1 \mathrm{~min}, 55^{\circ} \mathrm{C}$ and $95^{\circ} \mathrm{C}$ for $30 \mathrm{~s}$ each. GAPDH was used as a reference gene for the normalization of data. Fold change in gene expression was calculated with the $\mathrm{CT}$ values obtained by $\Delta \Delta \mathrm{ct}$ method.

\section{In-solution digestion}

The lyophilized proteins, $1 \mathrm{mg}$ of P1 and P4, were solubilized separately in $100 \mu \mathrm{l}$ of urea $6 \mathrm{M}$, and reducing agent $5 \mu \mathrm{l}$ DTT $(200 \mathrm{mM})$ was added. The samples were vortexed and incubated at room temperature for $1 \mathrm{~h}$. An alkylating agent, $20 \mu \mathrm{l}$ iodoacetamide $(200 \mathrm{mM})$ was added, and the mixture was incubated at room temperature in the dark for $1 \mathrm{~h}$. The reaction was stopped by adding $20 \mu \mathrm{l}$ of DTT, and urea concentration was reduced by diluting it with $775 \mu \mathrm{l}$ of MilliQ water. Digestion was carried out overnight $(<16 \mathrm{~h})$ by adding TPCK treated trypsin in a ratio of 1:30 (Trypsin: Protein). The next day, digestion was stopped by adding $10 \mu \mathrm{l}$ of acetic acid [22].

\section{Liquid chromatography and ultra-high-resolution mass spectrometry}

The tryptic peptides were separated on BioZen $2.6 \mu \mathrm{m}$ Peptide XB-C18 (pore size $100 \AA$, dimension $150 \times 2.1$ $\mathrm{mm})$ column (Phenomenex) and analyzed using Impact $\mathrm{II}^{\mathrm{sm}}$ UHR-QqTOF (Ultra-High Resolution Qq-Time-OfFlight) mass spectrometer (Bruker). The mobile phases used were $0.1 \%$ formic acid in water (solvent $\mathrm{A}$ ) and $0.1 \%$ formic acid in acetonitrile (solvent B). The flow rate was adjusted to $0.3 \mathrm{ml} / \mathrm{min}$ with following $85 \mathrm{~min}$ gradient: from 0 to $5 \mathrm{~min} 1 \% \mathrm{~B}, 5-60 \mathrm{~min} 50 \% \mathrm{~B}, 61-65$ $\min 50 \%$ B, 65-70 min 95\% B, 71-78 min 95\% B, 79-85 $\min 1 \% \mathrm{~B}$. 


\section{MS data analysis}

Mascot generic files (mgf) generated from raw MS/MS files were used to search against the SwissProttaxonomy Viridiplantae (39,582 sequences) database by using an in-house licensed Mascot search engine. Mascot search parameters were set as Carbamidomethylation of cysteine as a fixed modification, oxidation of methionine as variable modification, peptide mass tolerance allowed was $\pm 1.2 \mathrm{Da}$, fragment mass tolerance allowed was $\pm 0.6 \mathrm{Da}$ and trypsin as an enzyme with a maximum of one mixed cleavage permitted. The false discovery rate (FDR) was set as $1 \%$. Proteins identified with more than two matched peptides and greater than $99 \%$ probability were accepted.

\section{Gene ontology annotation and hydropathy profile}

The gene ontology annotation of the identified proteins was obtained from the UniProt Knowledgebase (UniProtKB) gene ontology (GO) project (https://www.uniprot.org/uniprot/). The proteins were categorized based on their molecular functions, biological process, and cellular localization. To calculate the grand average of hydropathy (GRAVY) value, the FASTA sequence of the identified proteins was obtained from the UniProt database, and the GRAVY values were computed using online ExPASy tool ProtParam (https://web.expasy.org/ protparam/).

\section{Statistical analysis}

SPSS version 20.0 software was used to analyze the data. One-way ANOVA (analysis of variance) and Dunnett's post-hoc test was used for comparing the treatment groups with control. Results with $P$ values $P<0.05$ were considered statistically significant whereas ${ }^{* * * *} P<0.001$, ${ }^{* *} P<0.01$ and $* P<0.05$.

\section{Results}

\section{Partial purification of Nigella sativa seed proteins}

The crude NS seed proteins were successfully precipitated from the extract prepared in PBS using 80\% ammonium sulfate. This step was employed to get rid of small molecules, including polysaccharides, nucleic acids, polyphenols, and pigments from the extract. Whereas, ammonium sulfate has no harmful effects on protein function and structure [23]. To evaluate the cytotoxic potential of the crude seed, precipitated proteins were partially purified on gel filtration chromatography column Hiload $^{\mathrm{Tm}}$ 16/60 Superdex ${ }^{\mathrm{Tm}} 200 \mathrm{pg}$ using ÄKTA start FPLC system. The proteins were eluted using an elution buffer PBS at $1 \mathrm{ml} / \mathrm{min}$ of flow rate, and absorbance was measured at $280 \mathrm{~nm}$. The eluted fractions were collected $5 \mathrm{ml}$ volume in each tube. Figure 1a shows the separation of the crude sample into seven peaks. All the peaks were collected and resolved on the gel. The Tris/glycine SDS-PAGE analysis of crude protein revealed the presence of several protein bands within a range of $\sim 2-150 \mathrm{kDa}$ (Fig. 1b). The SDS-PAGE profile clearly showed protein bands in a molecular weight range of $\sim 5-150 \mathrm{kDa}$ in peak 1 (P1), $\sim 15-100$ $\mathrm{kDa}$ in both peak 2 (P2) \& peak 3 (P3) and $~ 5-15 \mathrm{kDa}$ in peak 4 (P4) (Fig. 1b). Whereas peaks (P5, P6, and P7) did not show any protein band.

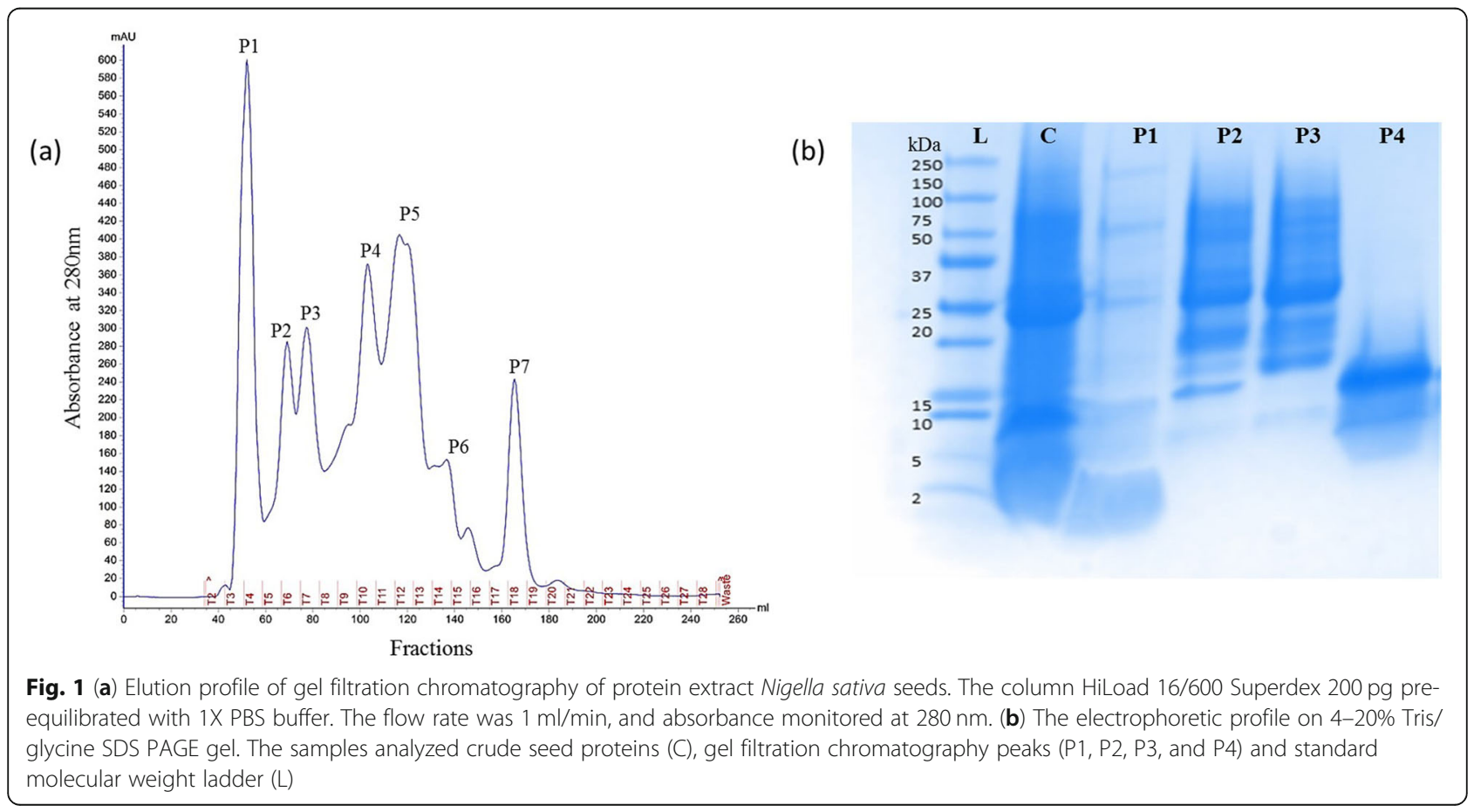




\section{Cytotoxic effect of Nigella sativa on human cancer cell line}

Prior to cytotoxic analysis, all the samples were desalted by ultrafiltration ( $3 \mathrm{kDa} \mathrm{MWCO}$ ) and quantified by Bradford assay. All the seven peaks and crude seed proteins were screened at different doses $(25,50$, 100,200 , and $400 \mu \mathrm{g} / \mathrm{ml}$ ) for their effect on the viability of MCF-7 cells. Among all test samples, P1 and $\mathrm{P} 4$ were found to be the most potent and inhibited cell proliferation in a dose-dependent manner after $48 \mathrm{~h}$ of treatment (Fig. 2a \& 2b). At $20 \mu \mathrm{g} / \mathrm{ml}$, P4 inhibited the growth and proliferation to almost $99 \%$ $\left({ }^{* * *} P<0.001\right)$ while $\mathrm{P} 1$ showed $56.57 \%\left({ }^{* * * *} \mathrm{P}<0.001\right)$ inhibition in MCF-7 cells. The $\mathrm{IC}_{50}$ values calculated were $14.25 \pm 0.84$ and $8.05 \pm 0.22 \mu \mathrm{g} / \mathrm{ml}$ for P1 and P4, respectively. Both $\mathrm{P} 1$ and $\mathrm{P} 4$ were more potent than standard drug doxorubicin $\left(\mathrm{IC}_{50}\right.$ value; $16 \pm 0.01 \mu \mathrm{g} / \mathrm{ml}$ ) (Fig. 2c). As shown in Fig. 3, treatment with P1 and P4 led to apoptosis related morphological changes in the cell, such as cell shrinkage and roundness of the cell. Phase contrast microscopy images clearly show a decrease in cell count in the treatment groups as compared to control. These results suggest that proteins from NS seeds exhibited significant inhibitory activity against MCF-7 cell line.

\section{Analysis of pro-apoptotic and anti-apoptotic genes}

To investigate whether $\mathrm{P} 1$ and $\mathrm{P} 4$ were responsible for inducing apoptosis in MCF- 7 cells, we examined the expression levels of pro-apoptotic (BAX and CASPASE-3) and anti-apoptotic (SURVIVIN and BCL-2) genes (Fig. 4). The intrinsic pathway is strictly regulated by bax to bcl-2 ratio. An increase in $B A X$ expression triggers mitochondria to release cytochrome c that, in return, activates caspases, while bcl-2 inhibits the release [24]. Here, we observed a significant 1.4-fold ( $\left.{ }^{* *} P<0.01\right)$ change upregulation in $B A X$ and a $0.8\left({ }^{* *} \mathrm{P}<0.01\right)$ fold change downregulation in $B C L-2$ gene expression after treatment with $\mathrm{P} 1$ at dose 10 and $14 \mu \mathrm{g} / \mathrm{ml}$, respectively (Fig. 4a). Subsequently, the expression of CASPASE-3 increased significantly to 1.7 -fold change $(* P P<0.01)$ at $14 \mu \mathrm{g} / \mathrm{ml}$ in $\mathrm{P} 1$. The calculated $B A X / B C L-2$ ratio, together with significant upregulation in the key executioner, CASPASE-3 indicates the presence of intrinsic/extrinsic pathway of apoptosis compared to control cells. In contrast, treatment with P4 did not show any change in bax to bcl-2 ratio when compared to untreated control cells. However, CASPASE-3 gene expression was found to be upregulated significantly by 1.4fold change $(* * \mathrm{P}<0.01)$ at $\mathrm{IC}_{50}$ dose of $8 \mu \mathrm{g} / \mathrm{ml}$, which may be due to activation of apoptosis by extrinsic pathway alone. SURVIVIN, a member of family inhibitors of
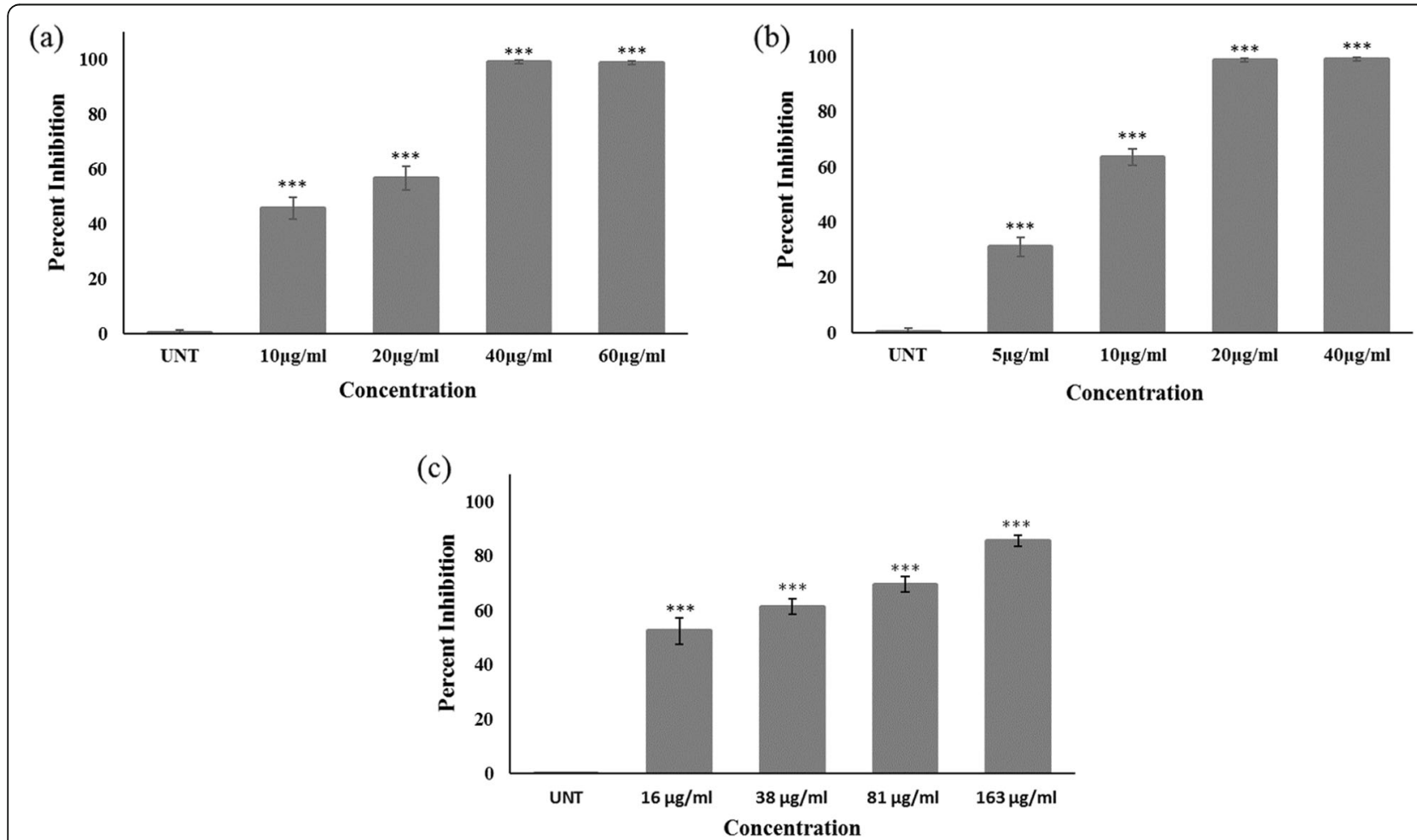

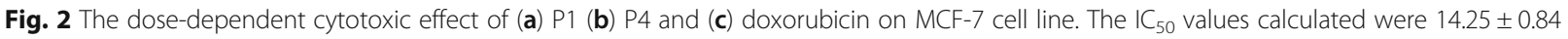
for P1, $8.05 \pm 0.22$ for P4 and $16 \pm 0.01 \mu \mathrm{g} / \mathrm{ml}$ for doxorubicin. Data are expressed as a mean of triplicates for each dose \pm S.D. from three independent experiments. UNT labeled bar represents untreated control cells. The statistically significant values are labeled as ${ }^{*} P<0.05$, ${ }^{*} P<0.01$ and ${ }^{* * *} P<0.001$ as compared to the control 


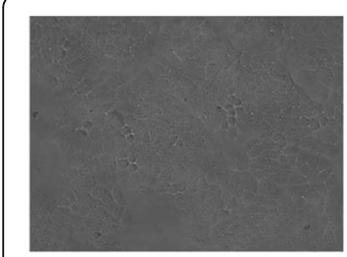

Control

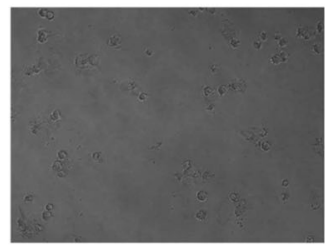

Doxorubicin

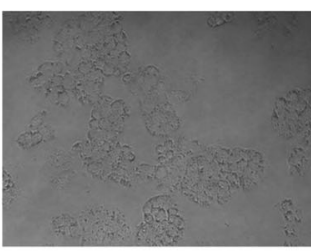

$\mathrm{P} 1-10 \mu \mathrm{g} / \mathrm{ml}$

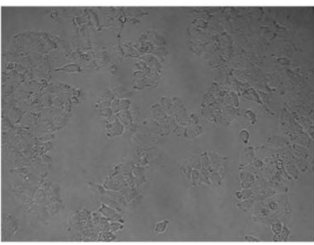

$\mathrm{P} 4-5 \mu \mathrm{g} / \mathrm{ml}$

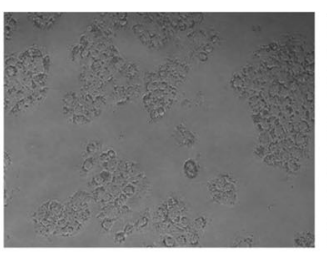

$\mathrm{P} 1-20 \mu \mathrm{g} / \mathrm{ml}$

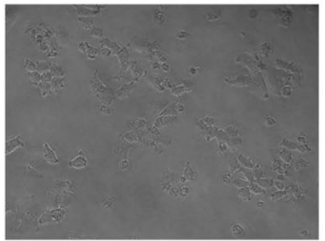

$\mathrm{P} 4-10 \mu \mathrm{g} / \mathrm{ml}$

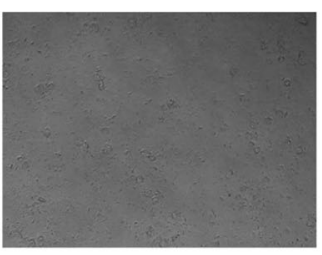

$\mathrm{P} 1-40 \mu \mathrm{g} / \mathrm{ml}$

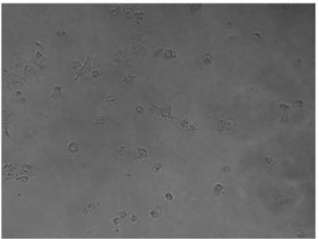

$\mathrm{P} 4-20 \mu \mathrm{g} / \mathrm{ml}$

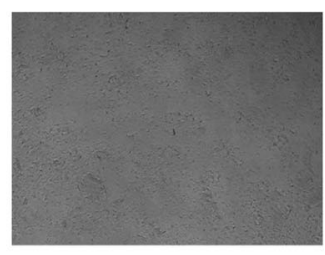

$\mathrm{P} 1-60 \mu \mathrm{g} / \mathrm{ml}$

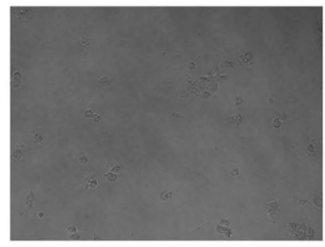

$\mathrm{P} 4-40 \mu \mathrm{g} / \mathrm{ml}$

Fig. 3 Phase contrast microscopy images of MCF-7 cells after treatment with P1 and P4

apoptosis (IAPs), was also significantly downregulated by both P1 and P4.

\section{Identification of proteins in P1 and P2 by LC-MS/MS}

To identify the proteins present in P1 and P4, insolution digestion was performed, followed by LCMS/MS, and a mass list obtained was searched against the UniProt database using the Mascot search engine. A list of proteins identified is presented in
Tables 1 \& 2. A total of 11 proteins were identified in P1 while 24 proteins in P4. Identified proteins from $\mathrm{P} 1$ and $\mathrm{P} 4$ represented a wide $\mathrm{pI}$ range from 5.5 to 11.4 and 4.7 to 9.9 , respectively, whereas mass range from 11.4 to $111 \mathrm{kDa}$ and 4.3 to $93.2 \mathrm{kDa}$, respectively. In $\mathrm{P} 1$, the highest significant score of 101 was observed for fructose-bisphosphate aldolase 8, while histone $\mathrm{H} 4$ had the highest $43.7 \%$ coverage. However, in P4, Protein SLE1 was the widely covered

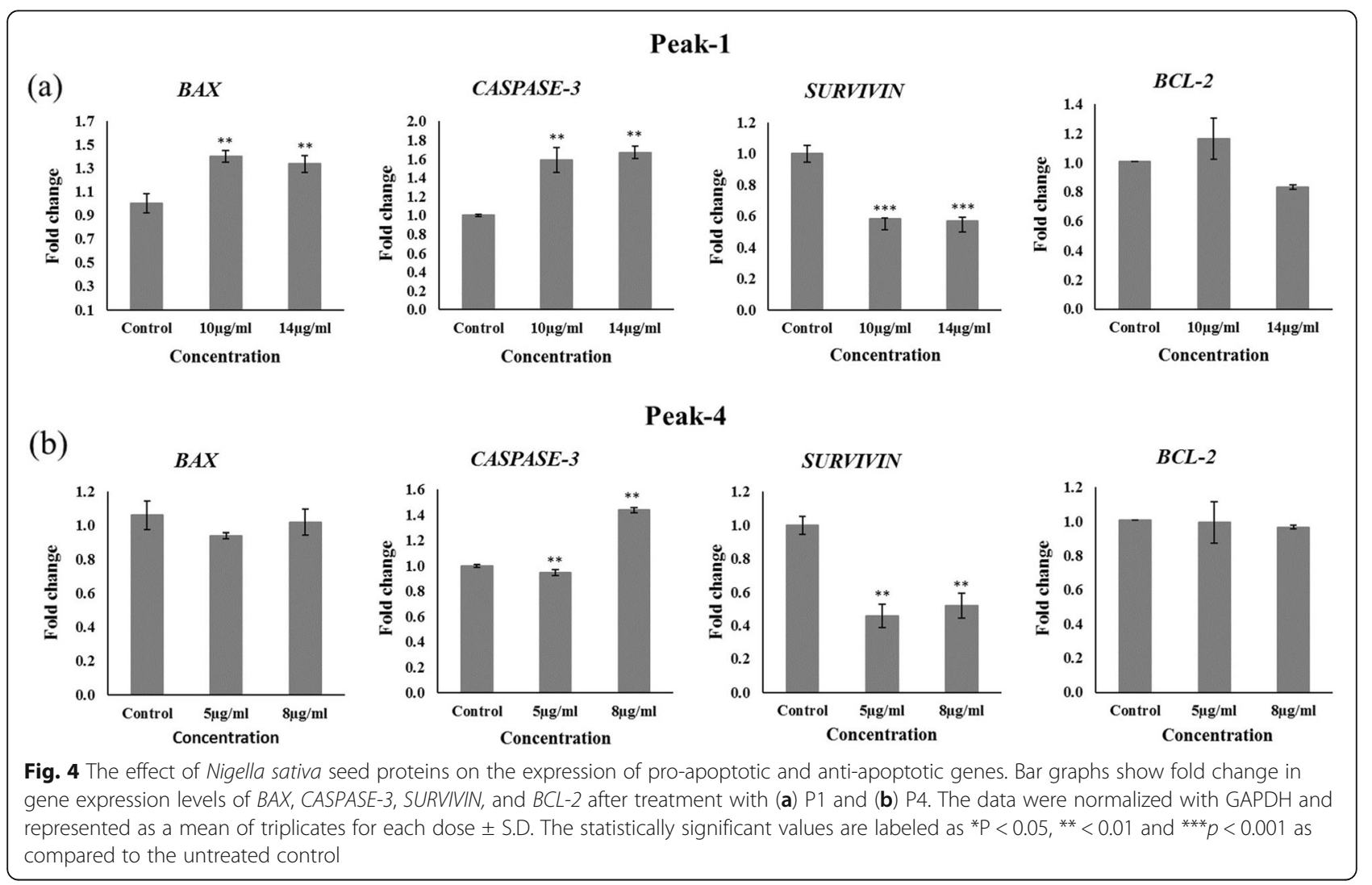


Table 1 The list of proteins identified by Mascot in peak 1(P1)

\begin{tabular}{|c|c|c|c|c|c|}
\hline Identified Protein & Accession No. & Score & Sequence Coverage \% & Molecular Mass kDa & $p l$ \\
\hline Fructose-bisphosphate aldolase 8 & Q9LF98 & 101 & 20.4 & 38.8 & 6.0 \\
\hline Glyceraldehyde-3-phosphate dehydrogenase 2 & Q7FAH2 & 86 & 32.9 & 36.9 & 6.3 \\
\hline Glucose and ribitol dehydrogenase homolog & Q75KH3 & 81 & 21.3 & 32.4 & 5.7 \\
\hline Peroxygenase & Q9SQ57 & 81 & 5.30 & 27.6 & 5.5 \\
\hline Enolase 2 & Q9LEI9 & 77 & 17.3 & 48.1 & 5.9 \\
\hline Histone $\mathrm{H} 4$ & Q71V09 & 75 & 43.7 & 11.4 & 11.4 \\
\hline Ubiquitin-60S ribosomal protein & B9DHA6 & 61 & 34.4 & 14.9 & 9.9 \\
\hline NADPH-dependent aldehyde reductase 1 & Q9FZ42 & 60 & 17.0 & 31.6 & 6.1 \\
\hline Proteasome subunit alpha type-7 & $\mathrm{O} 24030$ & 59 & 22.0 & 28.6 & 8.4 \\
\hline Phosphoenolpyruvate carboxylase & Q02909 & 58 & 18.5 & 111.0 & 5.6 \\
\hline Proteasome subunit beta type 4 & Q7DLR9 & 57 & 39.0 & 27.7 & 6.0 \\
\hline
\end{tabular}

protein with $83.9 \%$ coverage, and Dehydrin Rab15 presented the highest significant score of 189.

\section{Hydropathy profile}

The grand average of hydropathicity (GRAVY) value for all the identified proteins from P1 and P4 were calculated, as shown in Fig. 5. The proteins with positive scores are hydrophobic, and negative scores are hydrophilic. In $\mathrm{P} 4$, both positive and negative values were observed, indicating the presence of both hydrophobic and hydrophilic proteins with hydrophilic being in the majority. While in P1, GRAVY scores between -0.6 and -0.1 indicate only hydrophilic proteins.

Table 2 The list of proteins identified by Mascot in peak 4 (P4)

\begin{tabular}{|c|c|c|c|c|c|}
\hline Identified Protein & Accession No. & Score & Sequence Coverage \% & Molecular Mass kDa & $\overline{p l}$ \\
\hline Dehydrin Rab15 & Q00742 & 189 & 21.5 & 15.7 & 9.9 \\
\hline Carrot ABA-induced in somatic embryos 3 & Q5KTS7 & 180 & 32.7 & 12.1 & 6.1 \\
\hline Protein SLE1 & I1N2Z5 & 150 & 83.9 & 12.2 & 5.3 \\
\hline Em-like protein GEA6 & Q02973 & 85 & 14.1 & 9.9 & 6.7 \\
\hline Ubiquitin-NEDD8-like protein RUB1 & Q9SHE7 & 146 & 28.8 & 17.4 & 5.7 \\
\hline Phosphoglycerate kinase & P12783 & 135 & 21.7 & 42.1 & 5.6 \\
\hline 605 ribosomal protein $\mathrm{L} 12$ & O50003 & 99 & 14.5 & 17.9 & 9.0 \\
\hline ATP synthase subunit beta & Q01859 & 91 & 25.2 & 59.0 & 5.9 \\
\hline Enolase 1 & Q9LEJ0 & 88 & 34.6 & 48.0 & 5.5 \\
\hline Enolase & P42896 & 82 & 33.9 & 48.1 & 5.5 \\
\hline Bifunctional enolase $2 /$ transcriptional activator & P25696 & 43 & 33.3 & 47.9 & 5.5 \\
\hline Elongation factor 1 -alpha & P34824 & 84 & 12.1 & 49.4 & 9.2 \\
\hline Late embryogenesis abundant protein 31 & Q9LJ97 & 78 & 40.8 & 26.7 & 4.7 \\
\hline Em protein & P04568 & 66 & 41.9 & 9.9 & 5.5 \\
\hline Embryonic abundant protein 1 & P46520 & 66 & 26.3 & 10.1 & 5.5 \\
\hline Em protein $\mathrm{H} 2$ & Q08000 & 58 & 44.1 & 9.9 & 5.5 \\
\hline Triosephosphate isomerase & P12863 & 72 & 27.3 & 27.2 & 5.5 \\
\hline Thionin NsW1 & $\mathrm{COHJH} 9$ & 69 & 28.6 & 4.3 & 9.6 \\
\hline ADP-ribosylation factor GTPase-activating protein & Q5W7F2 & 60 & 10.5 & 93.2 & 8.3 \\
\hline Late embryogenesis abundant protein 1 & O49816 & 56 & 34.5 & 19.0 & 8.6 \\
\hline Alcohol dehydrogenase class-P & P06525 & 56 & 32.2 & 41.8 & 5.8 \\
\hline ATP synthase subunit alpha & P05493 & 55 & 23.3 & 55.2 & 6.0 \\
\hline Vicilin-like antimicrobial peptides $2-3$ & Q9SPL3 & 54 & 13.9 & 74.6 & 6.5 \\
\hline Glyceraldehyde-3-phosphate dehydrogenase & P34922 & 53 & 23.4 & 36.7 & 6.5 \\
\hline
\end{tabular}




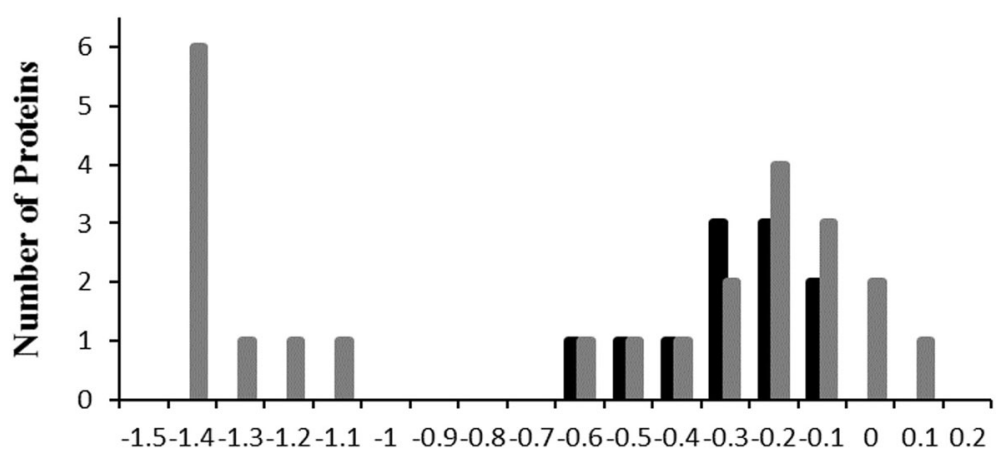

\section{GRAVY}

P1 P4

Fig. 5 Distribution of the grand average of hydropathicity (GRAVY) value for all the identified proteins in P1 and P4. Positive and negative values represent hydrophobic and hydrophilic proteins, respectively

\section{Gene ontology annotation}

The identified proteins were further categorized by UniProt GO annotation based on their cellular localization, biological process, and molecular functions, as shown in Fig. 6. Most of the proteins were found to be localized in cytosol (36\%), nucleus (29\%) and chloroplast (14\%) in P1 (Fig. 6a) while cytosol (56\%), nucleus (13\%) and mitochondrion (13\%) in P4 (Fig. 6b). In the category of biological process 40 and $29 \%$ of the identified proteins were involved in metabolic processes in $\mathrm{P} 1$ and $\mathrm{P} 4$, respectively. Other major proteins in $\mathrm{P} 1$ and $\mathrm{P} 4$ were associated with response to stress (20\%), and cellular process (17\%), respectively. Further molecular functional classification revealed for P1 was, binding activity (31\%), endopeptidase activity (13\%), dehydrogenase activity
(13\%), other catalytic activity (13\%) and for P4 binding activity (58\%), synthase activity $(16 \%)$ and hydratase activity (11\%).

\section{Discussion}

Since ancient times natural products have been used for the treatment of various ailments and remains to be a widely used form of complementary and alternative medicine (CAM) alongside allopathic drugs [25, 26]. Recent technological advancement has brought protein and peptide-based drugs into the spotlight. Plants have played a historically proven role in drug development and continue to offer an inexhaustible supply of novel drug leads [27]. Although $60 \%$ of the approved small molecule based anticancer drugs are plant-derived yet in

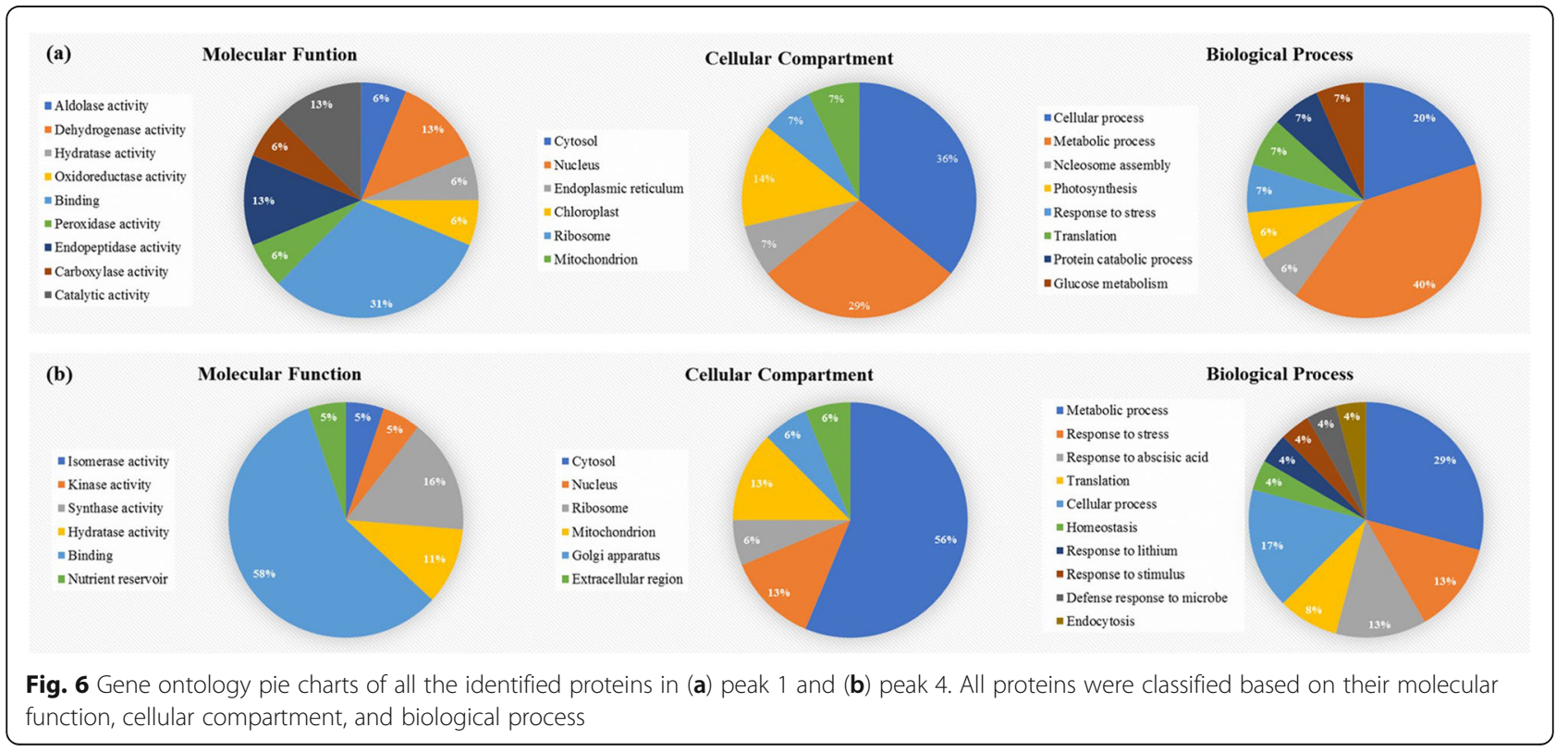


reality, only a handful of plants have been explored for the presence of antitumor proteins and peptides [5]. NS is one of the most extensively studied plants. Due to its wide spectrum of pharmacological activities, NS stands among the top-ranked herbal medicine [28]. Therefore, it is worthwhile to evaluate the anticancer potential of NS seed proteins.

In the present study, we successfully demonstrated the cytotoxic potential of partially purified NS seed proteins against MCF-7 cells. The crude seed proteins were successfully separated into seven peaks on the gel filtration chromatography column. The tris/glycine SDS PAGE analysis of both crude and FPLC fractions revealed the presence of multiple protein bands. Next, we screened all the peaks (P1, P2, P3, P4, P5, P6, and P7) and crude seed proteins for their cytotoxic effect. P1 and P4 found to be the most active against MCF-7, whereas no inhibitory activity was observed in the case of crude and peaks (P2, P3, P5, P6, and P7). Further, P1 and P4 were tested at different concentrations for $\mathrm{IC}_{50}$ calculations. Results showed dose-dependent inhibition in MCF-7 cells after $48 \mathrm{~h}$ of treatment. The $\mathrm{IC}_{50}$ value, a dose at which $50 \%$ inhibition observed were calculated as $14.25 \pm 0.84 \mu \mathrm{g} / \mathrm{ml}$ for P1 and $8.05 \pm 0.22 \mu \mathrm{g} / \mathrm{ml}$ for P4. These results were further supported by phase contrast microscopy images, which also showed a decrease in cell count with the increase in dose. Our results are in accord with the previous anticancer studies reported from proteins of medicinal plants Gynura procumbens (longevity spinach) [29], Corydalis cava (turkey corn) [30], Theobroma cacao (cocoa) [31] and Morinda pubescens (mulberry) [32].

In the subsequent experiment, we investigated the possible cell killing mechanism exerted by $\mathrm{P} 1$ and $\mathrm{P} 4$ on MCF-7 cells. Apoptosis, programmed cell death, is an important cellular process that is responsible for eliminating the mutated cancer cells [33]. It can be induced by extrinsic or intrinsic pathways. The intrinsic mitochondrial pathway is under the regulation of pro-apoptotic (e.g., Bax) and anti-apoptotic (e.g., Bcl-2) genes. The major player in apoptosis are caspases that are responsible for the execution of apoptosis. Evasion from apoptosis is the most prominent hallmark of cancer cells [34]. Hence, activation of apoptosis is an intriguing approach to fight against malignancy. Herein, apoptosis was induced in human breast MCF-7 cancer cells by modulating the expression of BAX, CASPASE-3, SURVI$V I N$, and $B C L-2$ genes (Fig. 4). At $14 \mu \mathrm{g} / \mathrm{ml}$ in P1, a significant upregulation in $B A X$ and a downregulation in $B C L-2$ led to an increase in the expression of CASPASE3 , an executioner of apoptosis. $B A X$ to $B C L-2$ ratio is important in determining the fate of the cell for life or death. Treatment with $\mathrm{P} 1$ led to a dose-dependent increased in $B A X$ to $B C L-2$ ratio, indicating the presence of a potential anticancer agent. While in the case of $\mathrm{P} 4$, no change in expression of $B A X$ and $B C L-2$ genes were observed; however, the CASPASE-3 gene expression was increased significantly, indicating the activation of the intrinsic pathway of apoptosis alone. Survivin, a member of inhibitors of apoptosis (IAPs), is a multifunctional protein that promotes angiogenesis, inhibits apoptosis, and controls cell proliferation [35]. Overexpression of survivin is associated with almost all types of breast cancer, including MCF-7 [36, 37]. We observed a significant decrease in SURVIVIN gene expression, which suggests apoptosis as a possible killing mechanism in MCF-7 following treatment with P1 and P4.

The active protein fractions were further analyzed using LC-MS/MS, and data acquired were searched against the Mascot database for protein identification. In P1, 11 proteins were identified, and the majority of them were located in the cytosol and hydrophilic in nature. Three proteins out of eleven, namely, proteasome subunit alpha type-7, proteasome subunit beta type-4, and ubiquitin-60S ribosomal protein, are from plant ubiquitin-proteasome system. Plant proteasome follows two routes for degradation of damaged or misfolded proteins, ubiquitin dependent proteolysis, and ubiquitin independent proteolysis [38]. The latter is crucial for the removal of oxidized proteins produced by reactive oxygen species [39, 40]. With its additional RNAase activity, these proteins offer protecting role against plant viruses such as the tobacco mosaic virus (TMV) [41, 42]. Nevertheless, the involvement of these proteins in the degradation of proteins and RNA of cancer cells needs further validation. Another identified protein, fructosebisphosphate aldolase 8 , belongs to the plant defense related proteins. This protein has been previously reported from Gynura procumbens [29] and Corydalis cava tuber [30] for their antiproliferative effect on MDA-MB-231 and HeLa cells, respectively. Other identified proteins in P1 were associated with plant metabolic and cellular processes, and their role as antitumor has not been studied yet.

In the case of $\mathrm{P} 4,24$ proteins, including one peptide, were identified. The majority of the identified proteins were hydrophilic in nature, located in the cytosol, and involved in the metabolic process. Thionin NsW1, an antimicrobial peptide (AMP) from NS was also identified in P4. Thionins from different plants are well studied for their anticancer activity, such as thionin from Pyrularia pubera (buffalo nut) was reported as cytotoxic to B16 mouse melanoma and HeLa cervical cancer cell lines [43]. Thionin, namely viscotoxins from Viscum spp induced apoptosis by upregulating the expression of caspase 3 in human lymphocytes [44]. Furthermore, thionin, Thi2.1 from Arabidopsis thaliana (mouse-ear cress) inhibited the growth of MCF-7, HeLa, and A549 cancer cell lines [45]. Another identified plant defense peptide vicilin in $\mathrm{P} 4$, also known as antimicrobial 
peptide (AMP), has been reported active against a variety of microbial species [46]. Recently, Gupta et al., have demonstrated the cytotoxic activity of mungbean vicilin protein hydrolysate against MDA-MB-231 and MCF-7 breast cancer cell lines. They have also studied the inhibitory effect of vicilin peptides on the angiogenesis converting enzyme (ACE) [47]. Herein, the antiproliferative and apoptotic effect by $\mathrm{P} 4$ could be attributed by vicilin and/or thionin. Whereas, the pharmacological significance of the other identified proteins in P4 has not been evaluated.

Our study is the preliminary demonstration of the anticancer effects of NS seed proteins. The active protein fractions consist of a mixture of plant proteins. In the future, a study will be designed to evaluate the effect of individual isolated protein and in combination on cancer cells. The synergistic effect exhibited by the mixture of proteins in $\mathrm{P} 1$ and $\mathrm{P} 4$ is an important finding. In fact, many effective phytomedicines in markets are a crude mixture of proteins such as bromelain, which is a crude mixture of various enzymes, including endopeptidases, glucosidase, cellulase, peroxidase, escharase, and phosphatase, from Ananas comosus (pineapple) fruit and stem [48]. Bromelain is used to treat pain, burns, inflammation, osteoarthritis, cancer, thrombophlebitis, and sport related injuries [49-53].

\section{Conclusion}

Presented studies successfully demonstrated the antiproliferative and apoptosis inducing potential of NS seed proteins on MCF-7 cells. The synergistic behavior by a mixture of protein in NS protein fractions is an interesting finding. This is the first study from NS seed in this context and may open an avenue in the future for plantbased protein pharmaceuticals. However, further studies are needed to isolate and purify the individual protein responsible for the In-vitro anticancer effect and to evaluate the underlying mechanism.

\section{Abbreviations}

ACE: Angiogenesis converting enzyme; AMP: Antimicrobial peptide; CAM: Complementary and alternative medicine; FDR: False discovery rate; FPLC: Fast protein liquid chromatography; GO: Gene ontology; GRAVY: Grand average of hydropathy; NS: Nigella sativa; P1: Peak-1; P4: Peak-4; PBS: Phosphate-buffered saline; TMV: Tobacco mosaic virus; UniProtKB: UniProt Knowledgebase

\section{Acknowledgements}

Yamna Khurshid gratefully acknowledges the fellowship support from Chapman University. Part of this research was completed using Analytical Core Facility, Chapman University School of Pharmacy, Irvine, California, USA, and International Center for Chemical and Biological Sciences, University of Karachi, Karachi, Pakistan.

Ethics approval and consent to participate Not Applicable.

\section{Authors' contributions}

S.U.S., O.B., A.A. conceived and designed the experiments. Y.K. performed all experiments for protein characterization, biological assay, and bioinformatics analysis. B.S. performed LC/MS/MS analysis. All authors contributed to writing, editing, and approved the manuscript for submission.

\section{Funding}

No funding was received.

Availability of data and materials

Data and materials are available from authors on reasonable request.

\section{Consent for publication}

Not Applicable.

\section{Competing interests}

The authors declare that they have no competing interests.

\section{Author details}

${ }^{1}$ Biomedical and Pharmaceutical Sciences, Chapman University School of Pharmacy, 9401 Jeronimo Road, Irvine, CA 92618, USA. ²Dr. Panjwani Center for Molecular Medicine and Drug Research, International Center for Chemical and Biological Sciences, University of Karachi, Karachi 75270, Pakistan.

Received: 30 July 2019 Accepted: 22 December 2019

Published online: 13 January 2020

\section{References}

1. Bray F, Ferlay J, Soerjomataram I, Siegel RL, Torre LA, Jemal A. Global cancer statistics 2018: GLOBOCAN estimates of incidence and mortality worldwide for 36 cancers in 185 countries. CA Cancer J Clin. 2018;68(6):394-424.

2. Wong RS. Apoptosis in cancer: from pathogenesis to treatment. J Exp Clin Cancer Res. 2011;30(1):87.

3. Unsain N, Barker PA. New views on the misconstrued: executioner caspases and their diverse non-apoptotic roles. Neuron. 2015;88(3):461-74.

4. Ghazanfar SA. Handbook of Arabian Medicinal Plants. Boca Raton: CRC Press; 1994. p. 110-1.

5. Cragg GM, Newman DJ, Yang SS. Natural product extracts of plant and marine origin having antileukemia potential. The $\mathrm{NCl}$ experience. J Nat Prod. 2006;69(3):488-98.

6. Gordaliza M. Natural products as leads to anticancer drugs. Clin Transl Oncol. 2007;9(12):767-76.

7. Fridlender M, Kapulnik Y, Koltai H. Plant derived substances with anti-cancer activity: from folklore to practice. Front Plant Sci. 2015;6:799.

8. Thundimadathil J. Cancer treatment using peptides: current therapies and future prospects. J Amino Acids. 2012;2012.

9. Craik DJ, Fairlie DP, Liras S, Price D. The future of peptide-based drugs. Chem Biol Drug Des. 2013;81(1):136-47.

10. Gerlach SL, Mondal D. The bountiful biological activities of cyclotides. Chronicles Young Scientists. 2012;3(3):169.

11. Sharma NK, Ahirwar D, Jhade D, Gupta S. Medicinal and pharmacological potential of nigella sativa: a review. Ethnobotanical Leaflets. 2009;2009(7):11.

12. Khare CP. Encyclopedia of Indian medicinal plants: rational Western therapy, Ayurvedic and Other Traditional Usage, Botany. Springer; 2004.

13. Al-Jassir MS. Chemical composition and microflora of black cumin (Nigella sativa L.) seeds growing in Saudi Arabia. Food Chem. 1992;45(4):239-42.

14. Nickavar B, Mojab F, Javidnia K, Amoli MA. Chemical composition of the fixed and volatile oils of Nigella sativa L. from Iran. Zeitschrift für Naturforschung C. 2003:58(9-10):629-31.

15. Tavakkoli A, Mahdian V, Razavi BM, Hosseinzadeh H. Review on clinical trials of black seed (Nigella sativa) and its active constituent, thymoquinone. J Pharmacopuncture. 2017 Sep;20(3):179.

16. Tavakkoli A, Ahmadi A, Razavi BM, Hosseinzadeh H. Black seed (Nigella sativa) and its constituent thymoquinone as an antidote or a protective agent against natural or chemical toxicities. IJPR. 2017;16(Suppl):2.

17. Vasilchenko AS, Smirnov AN, Zavriev SK, Grishin EV, Vasilchenko AV, Rogozhin EA. Novel thionins from black seed (Nigella sativa L.) demonstrate antimicrobial activity. Int J Pept Res Ther. 2017;23(2):171-80.

18. Rogozhin EA, Oshchepkova YI, Odintsova TI, Khadeeva NV, Veshkurova ON, Egorov TA, Grishin EV, Salikhov SI. Novel antifungal defensins from Nigella sativa L. seeds. Plant Physiol Biochem. 2011;49(2):131-7. 
19. Nazeer M, Waheed H, Saeed M, Ali SY, Choudhary MI, UI-Haq Z, Ahmed A. Purification and characterization of a nonspecific lipid transfer protein 1 (nsLTP1) from Ajwain (Trachyspermum ammi) seeds. Sci Rep. 2019;9.

20. Laemmli UK. Cleavage of structural proteins during the assembly of the head of bacteriophage T4. Nature. 1970;227(5259):680.

21. Hansen MB, Nielsen SE, Berg K. Re-examination and further development of a precise and rapid dye method for measuring cell growth/cell kill. J Immunol Methods. 1989;119(2):203-10.

22. Link AJ, LaBaer J. Solution protein digest. Cold Spring Harb Protoc. 2011; 2011(2):pdb-rot5569.

23. Boschetti E, Righetti PG. Low-abundance proteome discovery: state of the art and protocols. Newnes; 2013.

24. Ghobrial IM, Witzig TE, Adjei AA. Targeting apoptosis pathways in cancer therapy. CA Cancer J Clin. 2005;55(3):178-94.

25. Dias DA, Urban $\mathrm{S}$, Roessner U. A historical overview of natural products in drug discovery. Metabolites. 2012;2(2):303-36.

26. Robinson MM, Zhang X. The world medicines situation 2011, Traditional medicines: global situation, issues and challenges. World Health Organization, Geneva. 2011:1-2

27. Cragg GM, Newman DJ. Natural products: a continuing source of novel drug leads. Biochim Biophys Acta. 2013;1830(6):3670-95.

28. Ahmad A, Husain A, Mujeeb M, Khan SA, Najmi AK, Siddique NA, Damanhouri ZA, Anwar F. A review on therapeutic potential of Nigella sativa: a miracle herb. Asian Pac J Trop Biomed. 2013;3(5):337-52.

29. Hew CS, Khoo BY, Gam LH. The anti-cancer property of proteins extracted from Gynura procumbens (Lour.) Merr. PloS One. 2013;8(7):e68524.

30. Nawrot R, Wolun-Cholewa M, Bialas W, Wyrzykowska D, Balcerkiewicz S, Gozdzicka-Jozefiak A. Cytotoxic activity of proteins isolated from extracts of Corydalis cava tubers in human cervical carcinoma HeLa cells. BMC Complement Altern Med. 2010;10(1):78.

31. Preza AM, Jaramillo ME, Puebla AM, Mateos JC, Hernández R, Lugo E. Antitumor activity against murine lymphoma L5178Y model of proteins from cacao (Theobroma cacao L.) seeds in relation with in vitro antioxidant activity. BMC Complement Altern Med. 2010;10(1):61.

32. Thomas AS, Saravanakumar R, Gupta PV. Evaluation of cytotoxic activity of protein extracts from the leaves of Morinda pubescens on human cancer cell lines. Rev Bras. 2017;27(1):99-104.

33. Kerr JF, Wyllie AH, Currie AR. Apoptosis: a basic biological phenomenon with wideranging implications in tissue kinetics. Br J Cancer. 1972;26(4):239.

34. Ouyang L, Shi Z, Zhao S, Wang FT, Zhou TT, Liu B, Bao JK. Programmed cell death pathways in cancer: a review of apoptosis, autophagy and programmed necrosis. Cell Prolif. 2012;45(6):487-98.

35. Ryan BM, Konecny GE, Kahlert S, Wang HJ, Untch M, Meng G, Pegram MD, Podratz KC, Crown J, Slamon DJ, Duffy MJ. Survivin expression in breast cancer predicts clinical outcome and is associated with HER2, VEGF, urokinase plasminogen activator and PAI-1. Ann Oncol. 2006;17(4):597-604.

36. Choi KS, Lee $\mathrm{TH}$, Jung MH. Ribozyme-mediated cleavage of the human survivin mRNA and inhibition of the antiapoptotic function of survivin in MCF-7 cells. Cancer Gene Ther. 2003;10(2):87.

37. Jha K, Shukla M, Pandey M. Survivin expression and targeting in breast cancer. Surg Oncol. 2012;21(2):125-31.

38. Kurepa J, Smalle JA. Structure, function and regulation of plant proteasomes. Biochimie. 2008:90(2):324-35.

39. Bader N, Grune T. Protein oxidation and proteolysis. Biol Chem. 2006; 387(10/11):1351-5.

40. Pena LB, Pasquini LA, Tomaro ML, Gallego SM. 20S proteasome and accumulation of oxidized and ubiquitinated proteins in maize leaves subjected to cadmium stress. Phytochemistry. 2007;68(8):1139-46.

41. Pouch MN, Petit F, Buri J, Briand Y, Schmid HP. Identification and initial characterization of a specific proteasome (prosome) associated RNase activity. J Biol Chem. 1995;270(37):22023-8.

42. Ballut L, Petit F, Mouzeyar S, Le Gall O, Candresse T, Schmid P, Nicolas P, Badaoui $S$. Biochemical identification of proteasome-associated endonuclease activity in sunflower. Biochim Biophys Acta. 2003;1645(1):30-9.

43. Evans J, Wang YD, Shaw KP, Vernon LP. Cellular responses to Pyrularia thionin are mediated by $\mathrm{Ca} 2+$ influx and phospholipase A2 activation and are inhibited by thionin tyrosine iodination. Proc Natl Acad Sci. 1989;86(15): 5849-53.

44. Büssing A, Vervecken W, Wagner M, Wagner B, Pfüller U, Schietzel M. Expression of mitochondrial Apo2. 7 molecules and caspase-3 activation in human lymphocytes treated with the ribosome-inhibiting mistletoe lectins and the cell membrane permeabilizing viscotoxins. Cytometry. 1999;37(2): 133-9.

45. Loeza-Angeles $H$, Sagrero-Cisneros E, Lara-Zárate L, Villagómez-Gómez E, López-Meza JE, Ochoa-Zarzosa A. Thionin Thi2. 1 from Arabidopsis thaliana expressed in endothelial cells shows antibacterial, antifungal and cytotoxic activity. Biotechnol Lett. 2008;30(10):1713.

46. Tang SS, Prodhan ZH, Biswas SK, Le CF, Sekaran SD. Antimicrobial peptides from different plant sources: isolation, characterisation, and purification. Phytochemistry. 2018;154:94-105.

47. Gupta N, Srivastava N, Bhagyawant SS. Vicilin—a major storage protein of mungbean exhibits antioxidative potential, antiproliferative effects and ACE inhibitory activity. PLoS One. 2018;13(2):e0191265.

48. Maurer HR. Bromelain: biochemistry, pharmacology and medical use. CMLS. 2001;58(9):1234-45.

49. Neumayer C, Fügl A, Nanobashvili J, Blumer R, Punz A, Gruber H, Polterauer $P$, Huk I. Combined enzymatic and antioxidative treatment reduces ischemia-reperfusion injury in rabbit skeletal muscle. J Surg Res. 2006;133(2): $150-8$.

50. Akhtar NM, Naseer R, Faroogi AZ, Aziz W, Nazir M. Oral enzyme combination versus diclofenac in the treatment of osteoarthritis of the knee-a doubleblind prospective randomized study. Clin Rheumatol. 2004;23(5):410-5.

51. Barth $\mathrm{H}$, Guseo A, Klein R. In vitro study on the immunological effect of bromelain and trypsin on mononuclear cells from humans. Eur J Med Res. 2005;10(8):325.

52. Singer AJ, McClain SA, Taira BR, Rooney J, Steinhauff N, Rosenberg L. Rapid and selective enzymatic debridement of porcine comb burns with bromelain-derived Debrase ${ }^{\oplus}$ : acute-phase preservation of noninjured tissue and zone of stasis. Journal of Burn Care \& Research. 2010;31(2):304-9.

53. Baez R, Lopes MT, Salas CE, Hernandez M. In vivo antitumoral activity of stem pineapple (Ananas comosus) bromelain. Planta Med. 2007;73(13): 1377-83.

\section{Publisher's Note}

Springer Nature remains neutral with regard to jurisdictional claims in published maps and institutional affiliations.
Ready to submit your research? Choose BMC and benefit from:

- fast, convenient online submission

- thorough peer review by experienced researchers in your field

- rapid publication on acceptance

- support for research data, including large and complex data types

- gold Open Access which fosters wider collaboration and increased citations

- maximum visibility for your research: over $100 \mathrm{M}$ website views per year

At $\mathrm{BMC}$, research is always in progress.

Learn more biomedcentral.com/submissions 